\title{
Identity Crisis as Postcolonial Problematic in Muhammad Al-Fayturi's Songs of Africa and Sahar Khalifeh's The Inheritance
}

\author{
Abdulhamid Aly Muhammad Alansary \\ Ph.D. in English Literature and Criticism, dept., of English Language \\ and Literature, Faculty of Arts, Sohag University, Egypt
}

\begin{abstract}
Scholars have read Muhammad Al-Fayturi's Songs of Africa as unveiling the tragic consequences of slavery and colonization on the psyche of African people, while others have read Sahar Khalifeh's novel, The Inheritance, as depicting the issue of identity of women in a patriarchal order. They have, however, omitted the major issue at stake: the farreaching circumstance of identity crisis. The significance of this study comes from its attempt to answer the question: Does colonialism affect the identities of colonial subjects? This article, therefore, explores issues of identity crisis as represented in Sahar Khalifeh's novel The Inheritance (1997) and Muhammad Al-Fayturi's poems Songs of Africa. Sahar Khalifeh (1941-) and Muhammad Al-Fayturi (1930-) are two Arab writers, whose works can be categorized as postcolonial literature. By exposing the pains of her protagonist, Zayna, who is a hybrid character, and the pains of Palestinians inside their homeland, Sahar Khalifeh's work emphasizes the daring impacts of colonialism on the identities of Palestinians. Also, Muhammad Al-Fayturi's poetry exposes the cruelty of colonialism. Through his poetry, Al-Fayturi makes it clear that colonialism is responsible for identity crisis. It is also responsible for the destruction of Africa, his homeland, which is left barren after being liberated from colonizers. From the analysis of Khalifeh's novel and selected poetry of Al-Fayturi,
\end{abstract}


(ISSN : 2536 - 9555)

this work concludes that colonialism impacted greatly on the identity of colonial subjects both in Palestine and Sudan.

Keywords:

Identity Crisis, Postcolonial Literature, Songs of Africa, The Inheritance

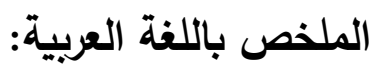

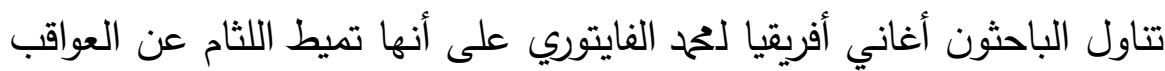

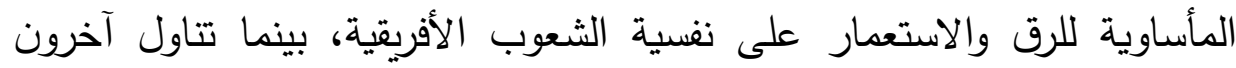

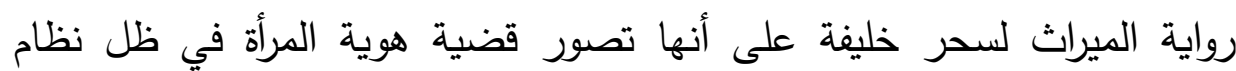

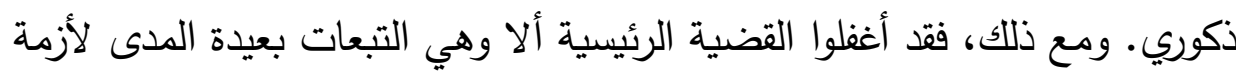

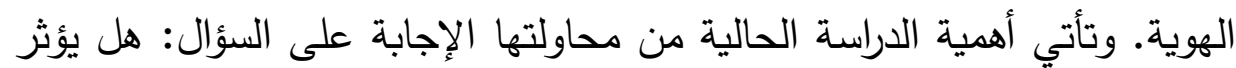
الاستعمار على هويات المستعمرين؟ لذلك, فإن هذا البحث يحاول تحري قضايا

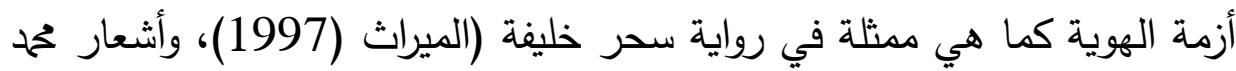

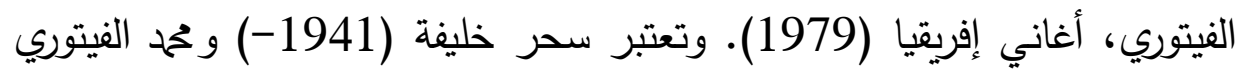

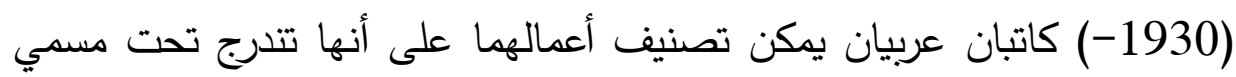

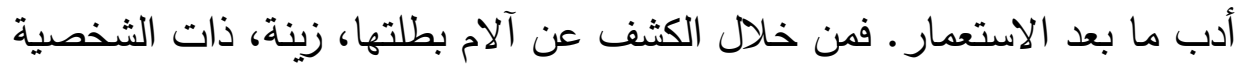
الهجينة ، وآلام الفلسطينيين داخل وطنهم، يؤكد عمل سحر خليفة على الآلثار

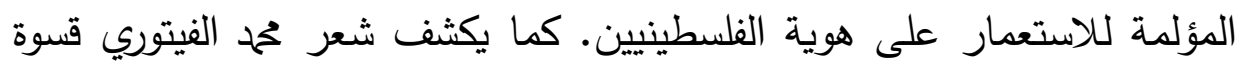

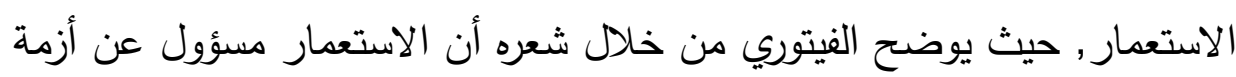

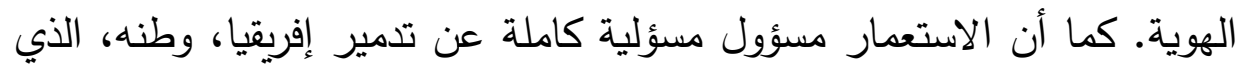

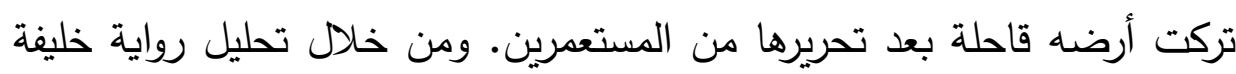

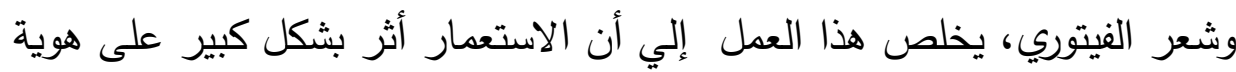
المستعمرين في كل من فلسطين والسودان.

الكلمات المفتاحية: أزمة الهوية، الأدب ما بعد الاستعماري، أغاني إفريقيا، 
Identity Crisis as Postcolonial Problematic in Muhammad Al-Fayturi's Songs of

Africa and Sahar Khalifeh's The Inheritance

Dr. Abdulhamid Aly Muhammad Alansary

مجلة وادي النيل للاراسات والبحوث الإنسانية والاجتماعية والتربوية (مجلة علمية محكمة)

\section{Introduction:}

The significance of the present study comes from its attempt to answer the question: Does colonialism affect the identities of colonial subjects? From the analysis of AlFayturi's poetry and Sahar Khalifeh's novel, this work concludes that colonialism impacted greatly on the identity of colonial subjects both in Palestine and Sudan.

Postcolonialism, as a term, is controversial with respect to definition and perspectives. Ashcroft (2012) points out that postcolonialism can be simply defined as the "branch of contemporary theory that investigates, and develops propositions about the cultural and political impact of European conquest upon colonized societies, and the nature of those societies' responses" (p. 6). The term also sets the boundaries between colonialism and the state of selfdetermination. Moreover, Postcolonialism is concerned more with the post-invasion circumstances rather than with the state of post-independence. Postcolonialism, as Ashcroft continues to point out, is "not 'after-colonialism' nor is it a way of being. Postcolonial is a way of reading - a way of reading the continuing engagement with colonial and neo-colonial power" (p. 6).

In The Empire Writes Back, Ashcroft (1989) states that "more than three-quarters of the people living of the world today have had their lives shaped by the experience of colonialism" (p. 1). Imperialism, which can be used synonymously to refer to colonialism, means power, authority, command, realm, and empire (Habib, 2005, p. 737). Imperial states, or colonizers, aim not only to extend their borders and add new colonies, but also to "impose ...its own political ideals, its own cultural values, and often its own language 
upon a subject state" (p. 737). Though they got their independence, most of these independent nations, or 'decolonized' nations, are still tied to colonizers, both culturally and economically. Therefore, decolonized nations challenge the control of colonizers as the power that shapes their identity as they look for a separate, independent cultural identity. When this is undertaken by scholars, it could be termed as postcolonial critique.

Postcolonial critique is not concerned with telling the story of decolonized nations. Rather, as Robert Young (2003) writes, it "focuses on forces of oppression and coercive domination that operate in the contemporary world: the politics of anti-colonialism and neo-colonialism, race, gender, nationalism, class and ethnicities define its terrain" (p. 11). The main concern with Postcolonialism is not its history; rather, the concern is with postcolonial narratives: how such narratives help in determining the cultural impact of colonizers on the colonial subjects.

\section{Identity Crisis in Postcolonial Literature:}

Postcolonial literature is literature that is written after independence, or after many countries got their independence. Writers of postcolonial literature see themselves as different to colonial powers. They have now a distinctive identity. In postcolonial literature, writers want to affirm their own identity, which is different from the colonizers' identity. In postcolonial literature and theory the question of identity and culture is of primary interest to writers. An essential element in discussing postcolonial literature is the impact of colonialism on the indigenous people, or the decolonized. The present study is concerned mainly with the impacts of colonialism on indigenous people. 
Identity Crisis as Postcolonial Problematic in Muhammad Al-Fayturi's Songs of

Africa and Sahar Khalifeh's The Inheritance

Dr. Abdulhamid Aly Muhammad Alansary

مجلة وادي النيل للاراسات والبحوث الإنسانية والاجتماعية والتربوية (مجلة علمية محكمة)

\section{Review of Literature}

Identity crisis in postcolonial literature is a prosperous area that has attracted the attention of a great number of scholars. Among the studies that have dealt with identity crisis in postcolonial literature are Saman Abdulqadir's study titled "The Crisis of Identity in Postcolonial Novel" (2015) and Sobia Kiran's study titled "Identity Crisis as Reflected in Selected Works: The Reluctant Fundamentalist by Mohsin Hamid and the Black Album by Hanif Kureishi" (2013). Saman's study deals with identity crisis in postcolonial novel. Although the study has dealt with a number of novels in previously colonized countries, it does not deal either with Sahar Khalifeh's novel or Muhammd Al-Fayturi's poetry. The study has emphasized the strong relation between colonialism and identity crisis. Sobia's study has dealt with identity crisis in The Reluctant Fundamentalist and Black Album, where the focus is on the identities of Pakistanis after the September11th events. The present study is concerned with the impacts of colonialism on the identities of the indigenous people in Palestine and the Sudan. It is the first study to take as an object of study two literary genres into account; namely, Muhammad Al-Fayturi's Songs of Africa and Sahar Khalifeh's The Inheritance. From the analysis of the two works, this work concludes that colonialism impacted greatly on the identity of colonial subjects both in Sudan and Palestine.

\section{IDENTITY, IDENTITY CRISIS AND POSTCOLONIAL THEORY:}

Merriam-Webster dictionary defines identity as the distinguishing character or personality of an individual. According to this definition, an identity is something that is 
stable and fixed. However, in postcolonial contexts, identity is not easily defined because in most cases it is naturally linked to what is called "Other". It is in such a context that identities suffer from a crisis. Thus, in postcolonial contexts, identity is always changing due to cultural and environmental factors.

The definition of identity crisis is still a matter of debate. Identity is a multi-faceted word that can mean many things. In psychology and sociology, an identity is a person's personal conception and expression of their individuality or their affiliation. This includes both national and cultural identities. The term identity comes from the Latin word identitas, which itself contains the suffix -tatis, meaning the same. Therefore, an identity can mean the distinctive characteristic features that belong to a given individual or a given social group. Dombrovskis (2016) points out: "identities emerge under the influence of the surrounding environment" (p. 308).

An identity is said to be experiencing identity crisis when it fails to achieve ego identity. Identity crisis occurs when an aspect of a personality is under challenge. This challenge can be religion or worldview, a challenge concerning nationalism or sexuality. Erikson (1998) defines identity as a subconscious process that merges a personality into a single whole and forms links between the individual and the social world. According to Erikson, identity crisis occurs when a person experiences insecurity and worries, which create a lack of knowledge and confusion about the present and the future in terms of the roles that they have.

When an individual experiences identity crisis, they become unable to face their societal problems and they are, therefore, subject to suffering. They are also unable to cope well with their problems and they will not be able to focus on their daily activities. As a result, they cannot figure out their identity because they are confused with the problems they are 
Identity Crisis as Postcolonial Problematic in Muhammad Al-Fayturi's Songs of

Africa and Sahar Khalifeh's The Inheritance

Dr. Abdulhamid Aly Muhammad Alansary

مجلة وادي النيل للاراسات والبحوث الإنسانية والاجتماعية والتربوية (مجلة علمية محكمة)

facing. (Fadhila, 2015). According to Fadhila, a person is said to have identity crisis when they start doubting about themselves or about their roles in life and their real selves. The crucial stage in identity crisis is when a person experiences a rapid change in their social life and they start to experience peer pressure and have the responsibilities to fulfill their roles in society. It is at this point in their development that individuals face obstacles, which prevent them of having a strong identity. As Erikson (2020) explains, this sort of unresolved crisis "leaves individuals struggling to "find themselves" (pp 109-110). They don't have any idea about who they are, where they belong, or where they want to go. They cannot make definitive choices about the future. (pp. 109-110).

In postcolonial literature, writers portray the impacts of colonialism on the indigenous. A major impact of the colonizer on the colonized is rupture of identity, which leads to identity crisis. Identity crisis is a significant issue in Postcolonial literature where topics such as race, gender, ethnicity, and, most importantly, identity and culture provoke discussions. Postcolonial societies are characterized by integration and alienation at the same time. Therefore, identities are no longer fixed and stable. Identities belonging to third world countries suffer the most since they are subject to frequent change. After being liberated from colonialism, decolonized nations face the problem of self-determination. The issue of identity becomes important when it is in crisis. That is, identity becomes in crisis when it is not fixed and stable because it is replaced by doubt. Mercer (1990) states: "identity only becomes an issue when it is in crisis, when something assumed to be fixed, coherent, and stable is displaced by the experience of doubt and uncertainty" (p. 43). 
مجلة وادي النيل للاراسات والبحوث الإنسانية والاجتماعية والتربوية (مجلة علمية محكمة)

(ISSN : 2536 - 9555)

Identity and culture are two controversial issues in Postcolonialism. The problem of identity is the most important since its crisis happens to be a significant issue in all postcolonial communities. After many countries got their independence, along with the increasing number of cultural diversities because of immigration, the issue of identity came to the fore. Pieterse (2002) explains that when colonial identities were decentered, after World War II, "the question of the 'Other' became a critical and prominent theme" (p. 22). It is in such situations that identities either appear to take a cue handed down by European colonizers or to revolt against and maintain their own identities and, therefore, build their own selves. Sahar Khalifeh and Muhammad Al-Fayturi are concerned with the construction of identities during colonization or after decolonization.

Instead of writing from an imperialist perspective, postcolonial writers, particularly novelists, write from a decolonized one. O'Reilly (2001) claims: "The label 'postcolonial' demands a shift in focus, away from British literature (colonizer's literature) to world literatures in English" (p. 7). As a result, postcolonial novelists write about issues of resistance, colonial experiences and their impacts on the colonized, and, most importantly, the construction of identity. As Fanon (1967b) maintains that the postcolonial novel in this respect is "a reply on a minor scale to the dominating power" (p. 237). In an attempt to form a stable identity, postcolonial writers portray the conflict of the colonized in finding a way between the heritage of the colonizers and the power of the dominant culture that is imposed on the colonized people. In Postcolonial narratives, fragmentation and identity crisis that have been experienced by the colonized people and the daring impacts of colonialism on indigenous people have been prominent issues. 
Identity Crisis as Postcolonial Problematic in Muhammad Al-Fayturi's Songs of

Africa and Sahar Khalifeh's The Inheritance

Dr. Abdulhamid Aly Muhammad Alansary

مجلة وادي النيل للاراسات والبحوث الإنسانية والاجتماعية والتربوية (مجلة علمية محكمة)

\section{FAYTURI AND KHALIFEH: THE RELATIONSHIP BETWEEN POETRY AND NARRATIVE:}

The twentieth century has witnessed an extraordinary flowering in fiction, poetry and drama from countries previously colonized by Britain. This literary production has played an important part in changing the whole map of English literature. This includes writings from postcolonial writers from Africa, Australia, and the Caribbean, India and other countries including Britain itself. In this way, authors shape communal identities and interrogate the values and representations of peoples in newly independent nations.

There is a point of commonality between Sahar Khalifeh's novel and Al-Fayturi's selection of poetry, even though they are in different literary modes. Both depict oppression, domination, and colonialism and the ensuing identity crisis they leave in their wake. Suffering is another common matter in the selected works. In her novels, Sahar Khalifeh is concerned with how her characters challenge colonialism, which is a direct reason for identity crisis. The establishment of a unique Palestinian identity is the primary concern of her novel. Establishing an identity can be achieved through going back to the roots, according to Khalifeh. This is clear in Zayna, the protagonist in The Inheritance. Also, it is clear in Nahleh, an important character in The Inheritance who sends money to fighters to support them in their fight against occupiers .

Similarly, Al-Fayturi's "Songs of Africa", though it is a collection of poems, deals with the establishment of identity as a postcolonial matter. Al-Fayturi calls, through his poetry, for the liberation of his people in The Sudan, in particular, and of all black people who live in different countries, in general. He devotes his poetry entirely to the cause of establishing an identity for the decolonized nations. This thematic similarity 
مجلة وادي النيل للاراسات والبحوث الإنسانية والاجتماعية والتربوية (مجلة علمية محكمة)

(ISSN : 2536 - 9555)

between Sahar Khalifeh's novel and Muhammad Al-Fayturi's poetry forms the strong link that makes it possible for this study to be formulated around both literary modes.

\section{IDENTITY CRISIS IN MMHAMMAD AL-FAYTURI AND SAHAR KHALIFEH:}

In this article, the analysis of selected works by Khalifeh and Fayturi focuses on the dialogues in Khalifeh's novel The Inheritance and the interpretations of selected poems by AlFayturi. The analysis of the dialogues depends largely on how the protagonist in Khalifeh's novel suffers from identity crisis due to occupation and how Palestinians are torn and divided between two worlds. In the case of Fayturi, the analysis focuses on his poetry, which evinces his own experience with identity crisis. During the analysis, a form of comparison and contrast between Khalifeh's and Fayturi's works will be done .

In spite of geographical differences, both Sahar Khalifeh and Muhammad Al-Fayturi, revolt against domination of people and land in their attempt to emphasize a unique identity. Although their works are not of the same literary genre, Sahar Khalifeh and Muhammad Al-Fayturi face such forces of oppression to establish a unique identity, an identity that is not a stereotype of colonizers.

Sahar Khalifeh's novel The Inheritance deals with such issues as resistance, exile, violence, and self-determination. In the same way, Muhammad Al-Fayturi's selected poetry is characterized by its concern with issues of race, class and colonialism. Sahar Khalifeh's novel exposes the problematic of identity crisis and alienation through the character of Zayna, the protagonist. Similarly, Muhammad Al-Fayturi's selected poetry exposes the problematic of identity crisis 
Identity Crisis as Postcolonial Problematic in Muhammad Al-Fayturi's Songs of

Africa and Sahar Khalifeh's The Inheritance

Dr. Abdulhamid Aly Muhammad Alansary

مجلة وادي النيل للاراسات والبحوث الإنسانية والاجتماعية والتربوية (مجلة علمية محكمة)

through a number of poems, which express the bad experiences impacts of colonialism on African people.

The search for identity is a postcolonial problematic in postcolonial narratives like Khalifeh's novel The Inheritance and the selected poetry of Muhammad Al-Fayturi. Third World identities like Zayna in The Inheritance suffer from identity crisis because they are subject to frequent change. They are divided between being subject to colonial identity and their attempt to get rid of this colonial identity and their attempt to establish a unique one for themselves. This is made obvious when Zayna, the protagonist of The Inheritance, decides to return to her homeland, leaving behind an academic career and a great fortune. Despite the fact that Zayna lives a prosperous life in diaspora, she is eager to know about her own identity. This makes Zayna return to her homeland in her search for her own culture and identity.

One of the significant impacts of colonialism on colonized nations and their culture is the problematic of shaping one's own identity. In The Inheritance, Sahar Khalifeh is concerned with resistance against colonialism and the establishment of Palestinian identity, which has been deformed as a result of the Israeli occupation and domination. She is also against the decentralization of the role of women in Palestinian resistance movement that followed the 1948 and 1967 wars. Sahar Khalifeh looks deeply into the Palestinian society and she cleverly depicts the sufferings of Palestinians under occupation. Through Zaynab, or Zayna, the protagonist, Sahar Khalifeh illustrates the disorienting experiences of living between two different worlds. Such disorienting experiences lead naturally to the search for identity. Being divided between two cultures and two worlds, Zayna is left without 
مجلة وادي النيل للاراسات والبحوث الإنسانية والاجتماعية والتربوية (مجلة علمية محكمة)

(ISSN : 2536 - 9555)

any identity. She doesn't find it either in America or in Palestine. She is torn between the two cultures.

In The Inheritance, Khlaifeh (2005) introduces the character of Zaynab or Zayna, who lived in a Western country and returned to her homeland. Zayna was born to a Palestinian father and an American mother. When she was fifteen she left Palestine to live with her grandmother in America. Living in America and bearing in mind Palestinian experiences, Zayna is torn between two different cultures. When she was forty, Zayna decided to return to her homeland. She returns to her roots, to her identity. She wants to emphasize her true cultural Palestinian identity when she said:

I did not say I was Arab because I wasn't. Who am

I then? Despite my mother's citizenship, my birth certificate, my school certificate, my books, my accent, my clothes, and everything about my life, I was not truly American. The depths of my mind were inhabited by visions and pictures, love songs, those Arabic mammals moving like the passage of a breeze, the scent of violets, the fragrance of memories, all leaving behind a honey-sweet solution in the heart" (p.17).

Zayna does not forget the Arabic side in her character: she still remembers her early experiences in Wadi -Alrihan, where she finds similarity between herself and other Palestinian women. Although Zayna feels peace in Wadi-Alrihan, she also feels alienation and confusion until the end of the novel. In an attempt to challenge the colonial culture, Zayna and Mazen establish the cultural center in Wadi-Alrihan. It is also an attempt to maintain their identity through maintaining language and culture.

When Zayna returned home, she faces a stark reality. Her dreams became illusions and she is left with such feelings of 
Identity Crisis as Postcolonial Problematic in Muhammad Al-Fayturi's Songs of

Africa and Sahar Khalifeh's The Inheritance

Dr. Abdulhamid Aly Muhammad Alansary

مجلة وادي النيل للاراسات والبحوث الإنسانية والاجتماعية والتربوية (مجلة علمية محكمة)

sadness and alienation. She feels as if she is a foreigner living in a foreign country. She is being isolated from her social group. At this moment, Zayna began her journey of discovering herself, her roots, and, most importantly, her identity. Soon, however, Zayna discovers that the people she meets are still genuine; they are not changed. All that she needs is to restore herself to life again and fell just as her people.

After the confrontation with her father because of her pregnancy at the age of fifteen, Zayna spends the great part of her time searching for her identity. Although she is successful on both academic and financial levels, Zayna is culturally lost. She is culturally lost because of her exposure to American culture. She is divided between her own Eastern culture and the Western culture. She is left in an area of vacuum. She is not completely American or completely Arab: "I did not say I was Arab because I wasn't...despite my mother's citizenship...my accent,.. I was not truly American" (p. 17). This makes her unable to decide for herself to which culture she actually belongs. Zayna becomes "chair of the anthropology department" and inherits the property of her American mother which is "two departments-one in Washington, one in San Diego," "two cars,"...and "diplomatic receptions" (p. 19). Despite all these possessions, Zayna lacks self-esteem. Zayna tells us: "despite this life of luxury, I felt deprived (p. 19). Although Zayna is academically and economically satisfied, she is deprived of the feeling of having an independent identity. She is culturally divided. All the possessions she owns do not make her feel self-respect; there is something that she lacks. She lacks the feeling of enjoying her Arab-Palestinian identity. 
مجلة وادي النيل للاراسات والبحوث الإنسانية والاجتماعية والتربوية (مجلة علمية محكمة)

(ISSN : 2536 - 9555)

Because she is a hybrid character, Zayna cannot bring reconciliation to the two opposing cultural aspects in her character. She combines the two cultures: The American and The Palestinian. Zaynab tells: " I was caught between two languages and two cultures-my father's Brooklyn and the West Bank on one side and my maternal grandmother's American culture on the other. I was later left without any culture and lived in vacuum" (p. 9). Because she is torn between two cultures, Zayna suffers from identity crisis. In fact, there is a direct reference her for the arduous impacts of colonialism on Zayna and other Palestinian characters.

When she receives a letter from her uncle telling her to claim her inheritance in the West Bank, Zayna is pleased to become part of her Palestinian roots again. Her share in the inheritance is not only about materialistic benefits but also about cultural ones. It adds to her cultural value, which has been divided between two cultures. Zayna becomes eager to know the Arab Palestinian culture to which she belongs. She tells us about this story:

I received a letter from my uncle saying what amounted to, "Come quickly before the thread breaks and you lose your claim to the inheritance". I lost no time thinking things over, but decided without hesitation. I felt at that moment as if I were standing before a window whose curtains were hiding the symbols of the country I had long dreamed of seeing. There was the affection of the family I had lost in my childhood and the warmth of my connection to the roots for which I had long searched in vain.

(p. 29)

Zayna is eager to discover the culture of her father and her community in Wadi Alrihan, West Bank. Her eagerness to see 
Identity Crisis as Postcolonial Problematic in Muhammad Al-Fayturi's Songs of

Africa and Sahar Khalifeh's The Inheritance

Dr. Abdulhamid Aly Muhammad Alansary

مجلة وادي النيل للاراسات والبحوث الإنسانية والاجتماعية والتربوية (مجلة علمية محكمة)

her country makes her imagine that there may be no possibility of seeing her father and relatives; of returning to her roots and her culture. She is waiting for the moment she sees the symbols of her country. When she comes back, Zayna will feel the affection of the family she lost when she was a child. It is an affection that she doesn't find in the other culture. She will also come back to her roots, which she has long been looking for. Although she finds her father sick and cannot know him because of his bad health, she finds relief in the surroundings of her father, brothers, and the environment. She is not deeply immersed in their life: she is just an observer who is not allowed to intervene in the matters of the family. She is looking for her identity which she may find in her father's face, in his surroundings, or in her relatives. She is looking for her identity in these factors because she left her homeland when she was young. This makes her spend the greater part of her life abroad, in a foreign land, though she lives with her grandmother. Leaving her homeland and living abroad is another impact of colonialism on Zayna.

In the same vein, Muhammad Al-Fayturi's Songs of Africa (1979) explores identity crisis as a postcolonial problematic. His selected poetry reflects the attitude of the poet toward essential issues such as oppression, racism, and identity crisis. Al-Fayturi depicts the disastrous impacts of colonialism on African people. He also expresses how such impacts lead directly to identity crisis. Al-Fayturi reconstructs the horrible experiences of black Africans via the poetics of anger. It is through the poetics of anger that Al-Fayturi challenges all forms of suppression and domination that are practiced against African people. Al-Fayturi talks about the humiliation that black people in Alexandria used to experience in the hands of European soldiers. Al-Fayturi renounces racism and supports 
(ISSN : 2536 - 9555)

any form of revolution against colonization and slavery. AlFayturi (1979) describes Africa under colonization as

the forgotten continent

and lost facts

the land of prophecies

the land of funerals

the land of the humiliated

under the colonizer's whips (p. 351).

For Al-Fayturi, African people are humiliated by colonizers and they live as foreigners in their homelands. They face daily hardships and brutalities form colonizers. He is aware of the catastrophic history of African people under colonialism.

Al-Fayturi expresses the crisis in the identity of black people who are torn between two cultures. He expresses his contradictory attitude toward the civilization of the New World as is represented in the city of New York:

O New York

whatever you have done to them

and whatever they have done to you

their souls will run toward you

they will bury their faces

in your arms shedding their tears

on your breast

because you are a mother

and a killer of prophets

a forest of death. (p. 443).

Al-Fayturi argues that although black Americans suffer greatly in the New World, they are not able to detach themselves from America. Although they suffer, black 
Identity Crisis as Postcolonial Problematic in Muhammad Al-Fayturi's Songs of

Africa and Sahar Khalifeh's The Inheritance

Dr. Abdulhamid Aly Muhammad Alansary

مجلة وادي النيل للاراسات والبحوث الإنسانية والاجتماعية والتربوية (مجلة علمية محكمة)

peoples' souls are closely connected with America; they will seek shelter in its arms, while shedding tears on its breasts. For the black people, New York is like a killing mother, or a forest of death. Al-Fayturi uses New York City as a symbol of the conflict between whites and blacks over identity. Although black people have built the city, it is not their homeland:

You are not my motherland

you have a heart of stone

which is not my heart

Africa is my land

the poor Negroes are my people (p. 441).

Black people in New York City suffer from agony and alienation. This causes them to suffer from a crisis in their identities: Do they belong, or not? It is the efforts of black people that have made the buildings of the New World possible. Although they live in America, blacks are proud of being part and parcel, not of America, but of Africa, their true homeland. When they find themselves torn between two cultures, black people return to their true culture, the African culture. This emphasizes their black identity.

In spite of their suffering in the New World, blacks are able to challenge such sufferings and combat colonialism. By challenging colonialism, black people are able to establish a stable identity for themselves. Although European colonizers used oppressive ways in Africa, black people could revolt against such culture and could maintain their own culture. Under colonization, African people live like strangers in their homelands. However, they could liberate themselves from the oppressive rule of colonizers. By liberating themselves, African people maintain their own identities and culture. As Khouri and Al-Gar (1974) note, Al-Fayturi is "dedicated to the liberation of his people" (p. 243). 
مجلة وادي النيل للاراسات والبحوث الإنسانية والاجتماعية والتربوية (مجلة علمية محكمة)

(ISSN : 2536 - 9555)

It is clear from the previous discussion that both Sahar Khalifeh and Al-Fayturi reject any cultural or economic ties with colonial forces. They look for an identity that is culturally and economically independent.

In postcolonial narratives, identities are no longer fixed and stable since postcolonial societies are characterized by integration and alienation at the same time. Third World identities suffer greatly since they are subject to frequent change. Sahar Khalifeh's novel, The Inheritance depicts the harsh life of Palestinian people under occupation. The setting of the novel is the city of Nablus after the 1967 war. Most of Arab lands came under the control of Israel and domination and oppression were the characteristic features of that period in Palestine. Sahar Khalifeh depicts the sufferings of Palestinian people under Israeli occupation and their search for identities in a postcolonial period.

In The Inheritance, Khalifeh explores national identity collectivism through introducing national discourse to expose the Palestinian dilemma. (Abu-Manneh, 2016). She introduces Zayna, an academic character, as suffering from being divided between two worlds: the American World, where she spent most of her life, and the Palestinian world, which she left when she was fifteen. Being divided between two worlds, Zayna feels as if without an identity. In an attempt to feel her own identity, Zayna decides to go back to her roots, to her origins, to her homeland. She finds her identity in her father's face, which she hardly recognizes; in her father's surroundings; and in her sisters, brothers and relatives. In fact, this is not the dilemma of Zayna only; it is the dilemma of all Palestinians, who live inside Palestine or outside in European or Arab countries.

Another important point that makes identity crisis clear is Sahar Khalifeh's portrayal of the cultural development and 
Identity Crisis as Postcolonial Problematic in Muhammad Al-Fayturi's Songs of

Africa and Sahar Khalifeh's The Inheritance

Dr. Abdulhamid Aly Muhammad Alansary

مجلة وادي النيل للاراسات والبحوث الإنسانية والاجتماعية والتربوية (مجلة علمية محكمة)

change that took place in Palestine after the 1948 war. Khalifeh tries to give an account of the Palestinian life after The Oslo Accords, which were signed between Israel and Palestine in 1993, 1995 respectively. The Oslo accords, I and II, aimed at fulfilling the right of the Palestinian people to self-determination. Putting Palestine under British mandate and then under Israeli occupation had bad effects on Palestinian identity. (Bauck \$ Omer, 2016).

Abu-Jabber, another character in The Inheritance, sees no changes in the life of Palestinians after The Oslo Accords. Abu-Jabber is led by disillusionment because he hoped for things to change after the Oslo Accords, but nothing happened. Abu-Jabber still embraces the values and culture of his homeland. Abu-Jabber's generation is torn between two worlds: a world of disillusionment, which they live, and a world of promised change for the better. They cannot catch up with, or even understand, the changes that took place around them in society.

Identity crisis, in postcolonial narrative, comes to the fore because colonized people are under domination and challenge. They are dominated by imperial powers and such domination makes them unable to enjoy and feel a stable identity. Therefore, they challenge domination to establish an identity for themselves.

By portraying the life of an immigrant in Zayna, who is torn between two cultures, Sahar Khalifeh attempts to make clear the problem of identity crisis. Zayna tries to adapt to both cultures and this makes her suffer. Displacement is another reason for increasing the suffering of Palestinians who live inside their country and those who live outside in other Arab countries. Displacement caused Palestinians to leave 
(ISSN : 2536 - 9555)

their country and live abroad and this played an important part in changing their identity. According to Litvak (2009), the Jewish occupation of Palestine is considered "the main cause of [their] identity change" (p. 13). This is clear in the characters of Zayna and Kamal who left their homeland and worked abroad.

Kamal is introduced to us as a scientist, who worked in Germany and had been given all advantages in life. However, he is divided between homeland and a prestigious world. Because his relation to homeland is deeper, Kamal never felt any advantage in Germany: "The Germans gave him a house, cars, and a bank account, health insurance and a pension; yet every morning as he rode the university bus or metro, he felt his loneliness and estrangement that never stopped growing" (Khalifeh, 2005, p. 153). His life in Germany is rootless. There is a feeling of alienation.

Sitt Amira and Abu-Jabber are two other characters that Khalifeh introduces to emphasize the split in the Palestinian identity. Sitt Amira, an educated old woman, supports resistance activities and provides medical care; Abu-Jabber is led by disillusionment because he hoped for things to change after the Oslo Accords, but nothing happened. Abu-Jabber still embraces the values and culture of his homeland. Sitt Amira and Abu-Jabber generation is torn between two worlds. They cannot catch up with, or even understand, the changes that took place around them in society. Both should work together for change to happen. As Said (1993) maintains that the changes that decolonized peoples aspire to cannot take place unless those people work together: "These changes cannot occur without the willingness of men and women to resist the pressure of colonial rule, to take up arms, [and] to project ideas of liberation..." (p. 241). This was on the level of political resistance. 
Identity Crisis as Postcolonial Problematic in Muhammad Al-Fayturi's Songs of

Africa and Sahar Khalifeh's The Inheritance

Dr. Abdulhamid Aly Muhammad Alansary

مجلة وادي النيل للاراسات والبحوث الإنسانية والاجتماعية والتربوية (مجلة علمية محكمة) .

On his part, Al-Fayturi celebrates African history and African sacrifices. He calls for reconstructing African identity and emphasizes African traditions, which are an integral part of African identity. His tool in doing so is poetry. Al-Fayturi believes strongly in literature as a tool of achieving African identity by affirming cultural values and traditions. In Songs of Africa, he identifies himself as a black African who sacrifices himself for the sake of his people and country. AlFayturi (1979) states:

I will not allow the white enemy

To occupy [my] Africa

I am a peasant

And Africa is my land

I have irrigated her soil

With my blood

I am a free man...in a free Africa

$\cdots$

Africa will remain a black land (p. 78)

Al-Fayturi identifies himself as a black who is proud of his blackness. At the same time, he will not allow a white enemy to occupy his land, Africa. African people have made many sacrifices for the sake of their own lands. They have irrigated its soil with their noble blood. Because they irrigated their lands with their blood, they are free and their land is also a free land and will remain so for ever.

Like Sahar Khalifeh in The Inheritance, Al-Fayturi's uses poetry to expose the black people's suffering under colonialism. He tells us that black people's suffering is caused by white European soldiers who are used to humiliating African people. He saw injustice and racism in the city of Alexandria. Therefore, he wanted to escape from the city. He did not bear seeing black people dominated and humiliated by 
مجلة وادي النيل للاراسات والبحوث الإنسانية والاجتماعية والتربوية (مجلة علمية محكمة)

(ISSN : 2536 - 9555)

European soldiers during World War II. He could not bear staying in "a city dominated by the white soldiers" (p. 45). Since it is dominated by White soldiers, Al-Fayturi is no longer able to live there. Alexandria becomes a disgusting place to live in as long as colonizers are still there. The city is not a safe place where one can feel dignity and identity. This sort of suffering leads to identity crisis. To emphasize his black identity, Al-Fayturi states:

Negro blood runs in the veins of my parents

I am black,

But I am free

Africa is my homeland (p. 80).

Al-Fayturi suffers from agony and pain because of colonialism. Al-Fayturi's poetry stands not only for himself but also for the whole African people. In his collection Songs of Africa, Al-Fayturi expresses the deep pain and tragic sufferings of Africans because of the historical humiliation of colonization:

You cannot understand the deep suffering of my tragedy because you didn't live my experience. Such complex and complicated feelings were resulted from the torments of history. The era of slavery has left its mark on the souls as well, not only on bodies" (p.25).

Al-Fayturi reveals the real and ugly face of colonization by depicting the harsh sufferings of colonized people. His poetry expresses solitude and alienation. There is a similarity between suffering of Muhammad Al-Fayturi and the character of Zayna in Sahar Khalifeh's The Inheritance.

Al-Fayturi experiences double identity crisis: one when he left his country to live in Alexandria with his family; and the 
Identity Crisis as Postcolonial Problematic in Muhammad Al-Fayturi's Songs of

Africa and Sahar Khalifeh's The Inheritance

Dr. Abdulhamid Aly Muhammad Alansary

مجلة وادي النيل للاراسات والبحوث الإنسانية والاجتماعية والتربوية (مجلة علمية محكمة)

other is the one experienced by all African and black people alike. In his poem "A Message to Khartoum" Al-Fayturi expresses his feelings of solitude and alienation:

Lost in alien countries

Dreaming of you

O my homeland

I creep on my sorrows

And the thorns of my bed

O my homeland

This sense of exile and alienation is intensified by

A curtain of tears

And a wall of gunfire

Colored by catastrophes

$\mathrm{O}$, my aimless people

Naked, tearful and dead

(p. 257)

Al-Fayturi explains that although he lives in an Arab city, he feels he is lost because he sees other Arab people humiliated at the hands of European soldiers in the city of Alexandria. He also dreams of returning to his own land, Sudan. The image in "I creep on my sorrows/And the thorns of my bed" is expressive of the pain that the poet finds while he is away from his homeland. The personification in "I creep on my sorrows" makes meaning clearer. It is as if the poet's sorrows are like the soil that a baby creeps on. The soil is not soft. That is why he is his body is supposed to be hurt. "The thorns of my bed" is another personification. The poet's bed is like a thorn that hurts. All these feelings of sorrow and pain are intensified by another image which makes the whole atmosphere of the stanza. The poet's sorrows are not visible; they are hidden behind "a curtain of tears and a wall of gunfire". The wall and the curtain do not prevent pain since 
they are "colored by catastrophes". The whole image is a disappointing one that makes the poet worried about his people, his "aimless people," who are "naked," without shelter; "tearful," and "dead".

The image in this stanza emphasizes identity crisis in the poetry of Muhammad Al-Fayturi. The poet is lost in strange countries, though he lives in Alexandria for a period of time. It is colonization, with its daring impacts on identities that makes the poet's feeling of estrangement great and unbearable. The poet suffers from identity crisis in Alexandria when he sees his people humiliated at the hands of colonizers. What makes the situation worse is the inner feelings the poet has about his people and his country. He is worried about losing his country and people at the hands of colonialism.

Al-Fayturi considers himself a foreigner, who lives in a foreign land though he belongs to the land and the land is part of him. He considers himself as a colonized poet talking about the sufferings of colonized people living in a colonized country. He highlights his sense of being African poet, not only an Arab, who revolts against domination of people and land in an attempt to emphasize black identity

Al-Fayturi's life in Alexandria is rootless, like Kamal in Sahar Khalifeh's The Inheritance. Al-Fayturi's suffering in Alexandria is caused by the humiliation of black people by European soldiers. This has caused him to leave the city for ever. He could not bear see his people humiliated before his eyes. Although Kamal has been given all sorts of a prestigious life, he felt loneliness and estrangement. Muhammad AlFayturi suffers from identity crisis as he sees his people humiliated in their homeland. Kamal feels identity crisis because of being divided between two cultures. 
Identity Crisis as Postcolonial Problematic in Muhammad Al-Fayturi's Songs of

Africa and Sahar Khalifeh's The Inheritance

Dr. Abdulhamid Aly Muhammad Alansary

مجلة وادي النيل للاراسات والبحوث الإسانية والاجتماعية والتربوية (مجلة علمية محكمة)

In an attempt to challenge colonial culture, Zayna and Mazen, in The Inheritance, establish the cultural center to maintain their identity. Similarly, Al-Fayturi highlights his deep sense of being a black African poet, not of being only an Arab poet. He revolts against domination and colonialism in order to emphasize his black identity. In The Inheritance, Sahar Khalifeh makes Abu Jabber celebrate national values and culture of his homeland. Similarly, Al-Fayturi celebrates his national culture, which emphasizes his own identity.

Al-Fayturi's poetry and Khalifeh's novel share something in common. In The Inheritance, Zayna, being born to a Palestinian father and an American mother, is torn between two cultures and, therefore, two identities. Similarly, AlFayturi is torn between being an Arab and African at the same time. He suffers from isolation and humiliation in Alexandria as an Arab, who lives in another Arab country. He also suffers from humiliation as an African who sees European soldiers humiliate African people. Both Khalifeh and Al-Fayturi emphasize the deep sense of alienation. When she becomes forty, Zayna decides to return to her homeland in an attempt to highlight national identity. Al-Fayturi celebrates African history and African sacrifices. He calls for reconstructing African identity by embracing African traditions, which are themselves part and parcel of African identity.

There are, however, several instances of commonalities in the perception of identity by both literary artists. Sahar Khalifeh and Muhammad Al-Fayturi emphasize the close relationship between identity crisis and colonialism. Both writers express their rejection of colonialism, which has resulted in the destruction of land and the loss of identity. AlFayturi sees Africa, under colonialism, as a barren land, which had been destroyed and divided. He compares between Africa 
before and after colonialism. Before colonialism, Africa was a fertile, peaceful, and lively land; after colonialism, it has become a wasteland, where cactus and woods are everywhere; there is no life except that of suffering and slavery. Similarly, Khalifeh portrays life after colonialism in Palestine. Life, both inside the country and outside it, has become unbearable: it is a sort of suffering and torment because of rigid rules which organize traveling and moving from one place to the other.

It is colonialism, with its audacity and bad effects that is responsible, in the first place, for the loss of the identities of colonized people. Identity crisis, for Khalifeh and Al-Fayturi, is a cultural crisis. That is, it is a matter of imposing one's culture upon the others by way of force and occupation. The only way to get rid of domination is to maintain one's own culture, language, customs, traditions, etc. More importantly is, therefore, to keep the land because it is the only heritage that contains everything about a nation's cultural heritage forever. It is through maintaining land that self-determination and resistance to colonialism can be achieved.

Whereas Khalifeh sees the challenge to identity crisis in her protagonists' ongoing attempts to face a sweeping colonial culture, the poetry of Al-Fayturi reveals the ugly and the real face of colonization by depicting the harsh sufferings of the colonized nations. Most of his poetry is about solitude and alienation. Muhammad Al-Fayturi and the protagonist in Sahar Khalifeh's novel suffer double identity crisis. The division in Al-Fayturi is an inner one, whereas in Khalifeh' novel, it is between the desire to keep one's identity inside his homeland or in his diasporic life.

Al-Fayturi's poem Songs of Africa and Khalifeh's novel The Inheritance portray resistance to slavery and racism, which have resulted in an identity crisis on the part of their people. They call for freedom and liberation for their people, 
Identity Crisis as Postcolonial Problematic in Muhammad Al-Fayturi's Songs of

Africa and Sahar Khalifeh's The Inheritance

Dr. Abdulhamid Aly Muhammad Alansary

مجلة وادي النيل للاراسات والبحوث الإنسانية والاجتماعية والتربوية (مجلة علمية محكمة)

and, above all, they are after establishing a stable identity for their people. The conflicting realities in the backgrounds of each writer have given rise to contradictory attitudes towards the culture and the identities of black Arab African/Asian people.

The poetry of Al-Fayturi is a personal experience. It portrays the problems of black Arab individuals who maintain their ethnic realities and identities. Al-Fayturi's poetry stands for the establishment of black African identity and against the devastation of his African identity.

Similarly, Khalifeh's novel The Inheritance is about maintaining one's identity in the face of a sweeping cultural colonization. The protagonist in the novel represents the same argument, though the resistance to racism and colonization takes different forms. Both writers exemplify the division and ambivalence in the identities of their peoples. Both writers give examples of unity in the face of racism and slavery by sticking to their original ethnic and cultural roots, in addition to combating the dominating culture of colonizers. By keeping their ethnic and cultural realities, colonized nations are able to dismantle antagonistic colonial culture about them and about their homelands.

Both Khalifeh and Al-Fayturi are aware of their everlasting link with their homelands. They portray images of their countries before the deformation of their culture, and, therefore, of their lands by the colonizers. Al-Fayturi sees no difference between Arab/non-Arab Africans: they live on the same land; they drink the same water; and they suffer from the same enemy. Khalifeh, also, sees no difference between inside and outside resistance (or as it is called by her Sumud) to colonization, or remaining in the homeland, whether people 
مجلة وادي النيل للاراسات والبحوث الإنسانية والاجتماعية والتربوية (مجلة علمية محكمة)

(ISSN : 2536 - 9555)

are forced to work in the occupier's factories or they left their homeland to earn a living for their families. For Al-Fayturi and Khalifeh, any division between Africans, on the one hand, and inside and outside Palestinian activists is not acceptable. Such divisions are artificial ones.

In his "Hadatha fi Ardi," Al-Fayturi sees Africa as one Africa, a united country. For Al-Fayturi Africa is an example of dignity and pride. He has deep faith in nothing but "in my people, in the history of my homeland, Africa," which he carries in his blood (Al-Fayturi, 1979, p. 108). Al-Fayturi describes the sufferings of his people under colonialism. He sees it under colonialism as a barren land. Similarly, Khalifeh describes the life of her people, whether inside Palestine or outside, as a life of tension. Khalifeh asserts that the life of Palestinians, inside and outside, takes the form of 'tension'. In her article Tension, Khalifeh (1984) claims: "our life under occupation cannot be described in one word. But if I were to do so, I think that no word would serve so well as 'tension': "Tension inside, tension outside" (p.26). What is even more important than the description of their life is that Palestinians are united in the face of colonialism: they suffer from tension whether they live inside their country or abroad. They share the same feelings of alienation and identity crisis.

\section{CONCLUSION}

Identity crisis is a principal problem colonized people, who are divided between two worlds and two cultures, face and suffer from. Those who suffer from identity crisis almost end as aliens in both worlds although they do their best to adapt to their environments. They are considered the "Other" even they are living in their homelands. Proclaiming one's identity is, thus, a difficult task because colonialism and colonial forces 
Identity Crisis as Postcolonial Problematic in Muhammad Al-Fayturi's Songs of

Africa and Sahar Khalifeh's The Inheritance

Dr. Abdulhamid Aly Muhammad Alansary

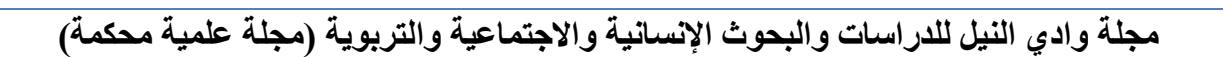

deprive an individual of their rights to do so. Victims of identity crisis are marginalized in their societies. They cannot feel freedom in society because they face threats of colonial forces, which dominate and oppress them. Identity crisis victims face absolute identity crisis whether in their own countries or outside as have been analyzed in both Khalifeh's The Inheritance and Fayturi's Songs of Africa. The only way out of having an identity crisis for an individual is to stick to one's language and culture because these are the medium through which values and customs of a certain group can prevail.

\section{References:}

Abu-Manneh, B. (2016). The Palestinian Novel: From 1948 to the Present. Cambridge: Cambridge University Press.

Al-Fayturi, M. (1979). The Complete Works of Al-Fayturi. Beirut: Dar Alawda.

Ashcroft, B. (2012). Introduction: Spaces of Utopias, Spaces of Utopias: An Electronic Journal, 2, (1), 1-17.

Ashcroft, B, Griffiths, G \$ Tiffin, H (1989). The Empire Writes Back: Theory and Practice in Postcolonial Literature. London and New York: Routledge.

Dombrovskis, A. (2016). Identity and Identity Crisis: The Identity Crisis of First-Year Female Students at Latvian Universities and their Sociodemographic Indicators. Proceedings of the International Scientific Conference on Society, Integration, Education, 1, 308-319.

Erikson, E. (1998). The Life Cycle Completed (Extended Version). London: W. W. Norton \& Company.

Erikson, E. (2020). "Erikson's Stages of Psychological Development" Available at https://en.wikipedia.org/wiki/Erikson\%27s stages of_psycho social_development. 
Fadhila, F. E. (2015). Bonnie Castle's Anxiety Disorder that Leads to Identity Crisis as Portrayed in William Irish's Waltz into Darkness, Allusion, 04, 02, 94-101.

Fanon, F. (1967). A Dying Colonialism. New York: Grove.

Habib, M. A. R. (2005). A History of Literary Criticism: From Plato to the Present. Oxford and MA: Blackwell Publishing Ltd.

Khalifeh, S. (2005). The Inheritance (A.Bamia, trans.). Cairo: The American University Press, (Original work published in 1997).

Khalifeh, S. (1984). Tension. The Iowa Review, 14 (2), 26-32.

Khouri, M. \$ Al-Gar, H. (1974). An Anthology of Modern Arabic Poetry. Berkeley: University of California Press.

Litvak, M. (ed.) (2009). (Ed.). Palestinian Collective Memory and National Identity. New York: Macmillan Palgrave.

Mercer, K. (1990) Welcome to the Jungle: Identity and Diversity in Postmodern Politics. In J. Rutherford (ed.), Identity: Community, Culture, Difference (pp. 43-72). London: Lawrence \& Wishart.

O`Reilly, C. (2001). Post-Colonial Literature. Cambridge: Cambridge University Press.

Bauck, P. \$ Omer, M. (2016). The Oslo Accords: A Critical Assessment. Cairo: The American University Press.

Young, R. (2003). Postcolonialism: A Very Short Introduction. Oxford: Oxford University Press.

Pieterse, J. N. (2002). Europe and Its Others: A Companion to Racial and Ethnic Studies. London: Blackwell University Press.

Said, E. (1993). Culture and Imperialism. London: Chatto and Windus. 